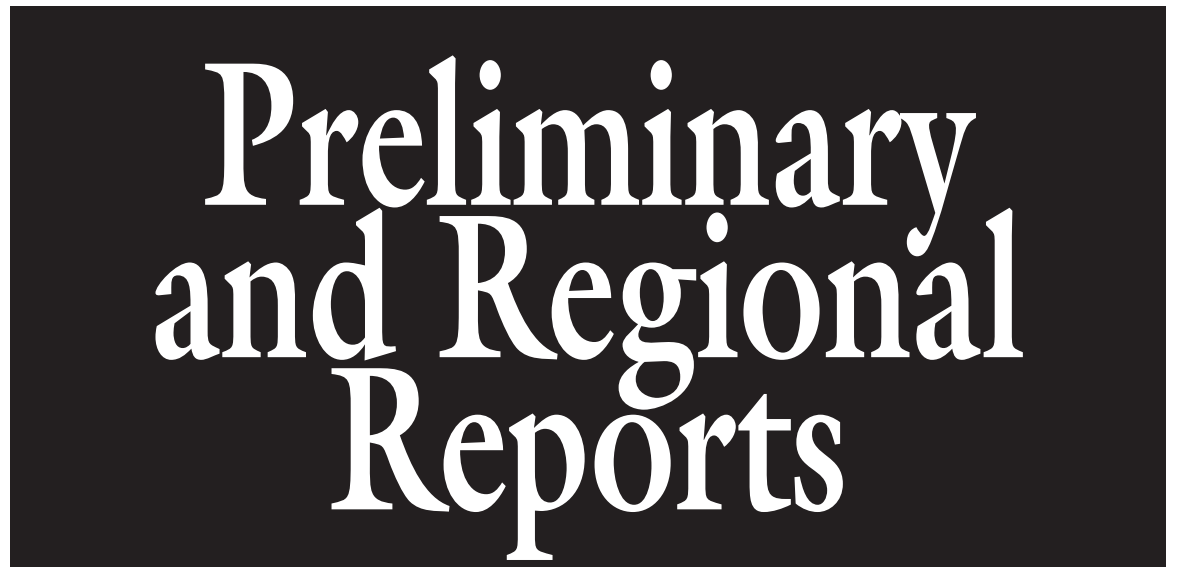

\section{Growth and Quality Response of Five Landscape-grown Herbaceous Perennials to Nitrogen Fertilization at Five Rates}

\author{
Gitta Shurberg ${ }^{1}$, Amy L. Shober ${ }^{2,8}$, Christine Wiese ${ }^{3}$, \\ Geoffrey Denny ${ }^{4}$, Gary W. Knox ${ }^{5}$, Kimberly A. Moore ${ }^{6}$, \\ and Mihai C. Giurcanu ${ }^{7}$
}

AdDitionAl INDEX WORDS. ornamental plants, aesthetic quality, landscape maintenance

\begin{abstract}
SUMMARY. There is limited research regarding proper fertilization rates and timing for landscape-grown herbaceous perennials. Most current nitrogen (N) fertilizer recommendations for landscape-grown perennials are based on rates for woody landscape plants or on rates for greenhouse-grown perennials. In addition, most fertilizer guidelines are defined to achieve peak growth, which may not be the best indicator of desirable plant quality. Basing fertilizer input rates on plant quality levels rather than maximum growth may result in a lower fertilizer application rate and a reduction in excess fertilizer available for leaching. The objective of this research was to evaluate the response of landscape-grown herbaceous perennials to $\mathrm{N}$ fertilizer applied at five rates. Five herbaceous perennials [bush daisy (Gamolepis chrysanthemoides), 'New Gold' lantana (Lantana Xbybrid), 'Mystic Spires' salvia (Salvia longispicata $\times$ farinacea), 'Evergreen Giant' liriope (Liviope muscari), and 'White Christmas' caladium (Caladium bicolor)] were transplanted into raised landscape beds containing subsoil fill in U.S. Department of Agriculture (USDA) hardiness zone 9a. Controlledrelease $\mathrm{N}$ fertilizer was applied at an annual $\mathrm{N}$ rate of $0,2,4,6$, and $12 \mathrm{lb} / 1000 \mathrm{ft}^{2}$ for 96 weeks. Plant size index (SI), tissue chlorophyll, and plant quality were measured every 6 weeks for 96 weeks. Flower cover was determined every 6 weeks from 42 to 96 weeks. Shoot biomass and tissue total Kjeldahl N (TKN) were measured at 96 weeks after planting (WAP). Regression analyses suggested that some species required in excess of $12 \mathrm{lb} / 1000 \mathrm{ft}^{2} \mathrm{~N}$ to reach maximum size, chlorophyll content, and shoot biomass. However, plants exhibited quality ratings of good to excellent at annual $\mathrm{N}$ rates of 2 to $4 \mathrm{lb} / 1000 \mathrm{ft}^{2} \mathrm{~N}$ per year. We suggest that these low to moderate levels of $\mathrm{N}$ fertilization ( 2 to $4 \mathrm{lb} / 1000 \mathrm{ft}^{2} \mathrm{~N}$ per year) will provide sufficient $\mathrm{N}$ to produce acceptable size and quality herbaceous perennials in the landscape.
\end{abstract}

$\mathrm{I}$ mproper fertilization of residential landscapes can result in water quality degradation because of nutrients [mainly nitrogen and phosphorus $(\mathrm{P})]$ in leachate or runoff. For example, Line et al. (2002) reported that average total $\mathrm{N}$ and $\mathrm{P}$ export from residential land uses was 256\% greater than the exports from wooded
(Line et al., 2002). However, there is limited research available regarding the proper fertilization (e.g., rate, timing, and/or application method) of landscape-grown perennials.

Most of the research focused on fertilizer requirements for perennial plant species was focused on achieving maximum growth and was conducted on containerized plants in a nursery or greenhouse setting (Dubois et al., 2000; Hipp et al., 1988; Macz et al., 2001; Nau, 1996). Nau (1996) reported that rates for producing optimal growth of herbaceous perennial plants during production generally fell within the range of 100 to $200 \mathrm{mg} \cdot \mathrm{L}^{-1}$ of $\mathrm{N}$ applied at every irrigation event or 100 to $150 \mathrm{mg} \cdot \mathrm{L}^{-1}$ of $\mathrm{N}$ applied weekly, depending on the species. Similarly, Hipp et al. (1988) reported maximum growth of container-grown autumn sage (Salvia greggii) was achieved when $\mathrm{N}$ was applied weekly at a rate of $200 \mathrm{mg} \cdot \mathrm{L}^{-1}$ and $\mathrm{P}$ was applied biweekly at a rate of $50 \mathrm{mg} \cdot \mathrm{L}^{-1}$; plants receiving $150 \mathrm{mg} \cdot \mathrm{L}^{-1} \mathrm{~N}$ and $30 \mathrm{mg} \cdot \mathrm{L}^{-1} \mathrm{P}$ had comparable growth. The authors concluded that tissue nutrient concentrations of autumn sage should be greater than $2.2 \% \mathrm{~N}$ and $0.20 \% \mathrm{P}$ to avoid limiting growth. Optimal growth of 'Margarete' anemone (Anemone $\times$ bybrida) was achieved when a complete fertilizer was applied three times per week at an $\mathrm{N}$ rate of $150 \mathrm{mg} \cdot \mathrm{L}^{-1}$ using a fertilizer with a ratio of $1: 2$ of ammonium to nitrate (Dubois et al., 2000). In addition, Macz et al. (2001) concluded that the minimum acceptable rate for production of container-grown 'White Diamond' chrysanthemum (Dendranthema grandiflora) was $100 \mathrm{mg} \cdot \mathrm{L}^{-1} \mathrm{~N}$ when additional $S$ was supplied at a rate of $10 \mathrm{mg} \cdot \mathrm{L}^{-1}$.

As was reported for containerized perennials, growth of perennial species generally increased with increasing $\mathrm{N}$ rate when grown in the landscape (Harbaugh and Overman, 1984; Wright et al., 2009). Wright et al. (2009) reported that the dry weight of 'Red Hot Sally' salvia (Salvia splendens) increased as fertilizer rates increased (from 27 to $42 \mathrm{~g}, 30$ to $35 \mathrm{~g}$, and 100 to $108 \mathrm{~g}$ dry weight when fertilized at 0,1 , and $2 \mathrm{lb} / 1000 \mathrm{ft}^{2} \mathrm{~N}$, respectively, depending on year and mulch treatment); however, fertilizer rate did not affect plant aesthetic quality. Similarly, tuber weight and production index of field grown caladium 
increased when $\mathrm{N}$ was applied at 200 or $300 \mathrm{lb} /$ acre compared with an $\mathrm{N}$ rate of $100 \mathrm{lb} /$ acre (Harbaugh and Overman, 1984). Cigar plant (Cuphea ignea), 'New Gold' lantana, and 'Goldsturm' rudbeckia (Rudbeckia fulgida) increased in size when they were supplied with $4 \mathrm{lb} / 1000 \mathrm{ft}^{2} \mathrm{~N}$ compared with $0, \mathrm{l}$, or $2 \mathrm{lb} / 1000 \mathrm{ft}^{2} \mathrm{~N}$ at five months after transplant; however, there were no differences in aesthetic quality of species receiving 1,2 , or $4 \mathrm{lb} / 1000$ $\mathrm{ft}^{2} \mathrm{~N}$ (Chen et al., 2011).

Even without substantial research to support $\mathrm{N}$ rate recommendations for landscape-grown perennials, broad recommendations are available. Rose (1999) surveyed existing extension bulletins related to $\mathrm{N}$ fertilization for field- and landscape-grown perennials and reported that $\mathrm{N}$ rate recommendations generally fell between 48 and $287 \mathrm{~kg} \cdot \mathrm{ha}^{-1}$. However, the authors noted that guidelines for selecting a rate within the range for a particular species were lacking (Rose, 1999). Similarly, Park-Brown (2011) recommended fertilizing perennials in the Florida landscape, but noted that optimal rates and timing will likely vary by species and soil type. The current fertilizer $\mathrm{N}$ rate recommendations from the state level extension program, University of Florida-Institute of Food and Agricultural Sciences (UF-IFAS) Florida Friendly Landscaping $^{\mathrm{TM}}$, are divided into low $(0$ to $2 \mathrm{lb} / 1000 \mathrm{ft}^{2}$ ), medium ( 2 to 4

Gulf Coast Research and Education Center, IFAS, University of Florida, 14625 CR 672, Wimauma, FL 33598

The work was supported by the Florida Agricultural Experiment Station, the Southwest Florida Water Management District, and the Florida Nursery Growers and Landscape Association.

${ }^{1}$ Biologist, Soil and Water Science Department, Gulf Coast Research and Education Center, IFAS, University of Florida, 14625 CR 672, Wimauma, FL 33598

${ }^{2}$ Assistant Professor, Department of Plant and Soil Sciences, University of Delaware, 531 South College Avenue, Newark, DE 19716

${ }^{3}$ Research and Extension Assistant, Environmental Horticulture Department, IFAS, 106 Building 68, Gainesville, FL 32611

${ }^{4}$ Consulting Horticulturist, G.C. Denny Horticulture, 12905 County Road 675, Parrish, FL 34219

${ }^{5}$ Professor, Environmental Horticulture Department, North Florida Research and Education Center, IFAS, University of Florida, 155 Research Road, Quincy, FL 32351

${ }^{6}$ Professor, Environmental Horticulture Department, Ft. Lauderdale Research and Education Center, IFAS, University of Florida, 3205 College Ave., Davie, FL 33314

${ }^{7}$ Statistical Research Coordinator, Department of Statistics, Statistical Consulting Unit, IFAS, University of Florida, 418 McCarty Hall C, Gainesville, FL 32611

${ }^{8}$ Corresponding author. E-mail: ashober@udel.edu. $\mathrm{lb} / 1000 \mathrm{ft}^{2}$ ), and high (4 to $6 \mathrm{lb} /$ $\left.1000 \mathrm{ft}^{2}\right)$ maintenance categories with no guidance available for selecting the appropriate category (Florida Department of Environmental Protection, 2010). Moreover, the current Florida Friendly Landscaping ${ }^{\mathrm{TM}}$ fertilizer recommendations were based on research evaluating the response of landscape-grown trees and shrubs to supplemental fertilization (Sartain et al., 2009), but the recommendations are routinely applied to all types of landscape-grown ornamentals (e.g., annuals, perennials, shrubs, etc.). Therefore, it is clear that additional research is needed to evaluate current fertilizer rate recommendations for a broader set of ornamental landscape plant types, such as perennials. The objective of this research was to evaluate plant response of selected landscape-grown herbaceous perennial species to $\mathrm{N}$ fertilizer applied at various rates. Results of this research will be used to provide more detailed guidance for the $\mathrm{N}$ fertilization of perennials in the landscape. The overall goal is to reduce the potential for fertilizers to be applied in excess of plant needs, which will reduce the likelihood that these nutrients impact water quality because of losses in runoff or leachate.

\section{Materials and methods}

Plant material. Five herbaceous perennials (bush daisy, 'New Gold' lantana, 'Mystic Spires' salvia, 'Evergreen Giant' liriope, and 'White Christmas' caladium) representing a variety of monocot and dicot species that are commonly planted in Florida landscapes were selected for evaluation of plant growth and quality response to $\mathrm{N}$ fertilizer when grown in the landscape. Bush daisy, lantana, and salvia were received as plugs (144 cell tray with $1 \times 1 \times 1.5$ inch individual cells) from Riverview Flower Farm (Riverview, FL); plugs were grown in 4-inch azalea pots (Reb Plastic, Orlando, FL) for $\approx 6$ weeks before field transplant. Species received as plugs were fertilized before planting using $21 \mathrm{~N}-3.1 \mathrm{P}-5.8 \mathrm{~K}$ liquid fertilizer twice per week at an $\mathrm{N}$ rate of $500 \mathrm{mg} \cdot \mathrm{L}^{-1}$. Caladium tubers were received from Bates Sons and Daughters (Lake Placid, FL) and were not fertilized before planting. Liriope was received in 1 -gal pots from $\mathrm{J} \& \mathrm{R}$ Nursery (Dover, FL) on 2l May 2008.

Experimental DESIGN. Fifteen raised beds $(10 \times 40 \times 0.5 \mathrm{ft})$ were established at the UF-IFAS Gulf Coast Research and Education Center in Wimauma, FL, which is located in USDA hardiness zone 9a. All raised beds were filled with St. Johns fine sand subsoil [sandy, siliceous, hyperthermic Typic Alaquods (USDA, 2004)] subsoil collected from a local borrow pit. Soil material from this borrow pit is commonly used as "topsoil" fill in new residential construction areas of west-central Florida. Before construction of the landscape beds, an initial composite soil sample was air-dried, passed through a $2-\mathrm{mm}$ screen, and analyzed for soil $\mathrm{pH}$ (1:2 soil to deionized water ratio), Mehlich 1 soil nutrients $[\mathrm{P}$, potassium $(\mathrm{K})$, calcium $(\mathrm{Ca})$, magnesium $(\mathrm{Mg})$, zinc $(\mathrm{Zn})$, and iron $(\mathrm{Fe})$, copper $(\mathrm{Cu})$, and manganese $(\mathrm{Mn}) ; \mathrm{l}: 4$ ratio of soil to 0.0125 M sulfuric acid $\left(\mathrm{H}_{2} \mathrm{SO}_{4}\right)+$ $0.05 \mathrm{M}$ hydrochloric acid $(\mathrm{HCl})]$ (Mylavarapu, 2009), and soil inorganic N (Mulvaney, 1996) using standard methods. Mehlich 1 nutrients were analyzed using inductively coupled plasma-atomic emission spectroscopy (Perkin Elmer, Waltham, MA). Soil nitrate + nitrite $\left(\mathrm{NO}_{3}+\mathrm{NO}_{2}-\mathrm{N}\right)$ [U.S. Environmental Protection Agency (USEPA), 1993a] and ammonium

\begin{tabular}{llll}
\hline $\begin{array}{l}\text { Units } \\
\text { To convert U.S. to SI, } \\
\text { multiply by }\end{array}$ & U.S. unit & SI unit & $\begin{array}{l}\text { To convert SI to U.S., } \\
\text { multiply by }\end{array}$ \\
\hline 0.3048 & $\mathrm{ft}$ & $\mathrm{m}$ & 3.2808 \\
0.0929 & $\mathrm{ft}^{2}$ & $\mathrm{~m}^{2}$ & 10.7639 \\
3.7854 & gal & $\mathrm{L}$ & 0.2642 \\
2.54 & inch(es) & $\mathrm{cm}$ & 0.3937 \\
25.4 & inch(es) & $\mathrm{mm}$ & 0.0394 \\
6.4516 & inch & $\mathrm{cm}^{2}$ & 0.1550 \\
16.3871 & inch & $\mathrm{cm}^{3}$ & 0.0610 \\
48.8243 & ib/l000 $\mathrm{ft}^{2}$ & $\mathrm{~kg} \cdot \mathrm{ha}^{-1}$ & 0.0205 \\
1.1209 & $\mathrm{lb} / \mathrm{acre}$ & $\mathrm{kg} \cdot \mathrm{ha}^{-1}$ & 0.8922 \\
28.3495 & $\mathrm{oz}$ & $\mathrm{g}$ & 0.0353 \\
1 & $\mathrm{ppm}$ & $\mathrm{mg} \cdot \mathrm{kg}^{-1}$ & 1 \\
1 & $\mathrm{ppm}$ & $\mathrm{mg} \cdot \mathrm{L}^{-1}$ & 1 \\
$\left({ }^{\circ} \mathrm{F}-32\right) \div 1.8$ & ${ }^{\circ} \mathrm{F}$ & ${ }^{\circ} \mathrm{C}$ & $\left({ }^{\circ} \mathrm{C} \times 1.8\right)+32$ \\
& & &
\end{tabular}


$\left(\mathrm{NH}_{4}-\mathrm{N}\right)$ (USEPA, 1993b) were analyzed colorimetrically on a discrete analyzer (AQ2; Seal Analytical, Mequon, WI). The initial soil $\mathrm{pH}$ was 4.77 and Mehlich 1 P, K, Ca, Mg, Zn, and Fe were $250,5.30,434,28.7,0.52$, and 4.08 $\mathrm{mg} \cdot \mathrm{kg}^{-1}$, respectively. Mehlich $1 \mathrm{Cu}$ and Mn concentrations were below the detection limit $\left(<4 \mathrm{mg} \cdot \mathrm{kg}^{-1}\right)$. Initial soil $\mathrm{NO}_{3}+\mathrm{NO}_{2}-\mathrm{N}$ and $\mathrm{NH}_{4}-\mathrm{N}$ were 1.22 and $2.69 \mathrm{mg} \cdot \mathrm{kg}^{-1}$, respectively. Soil $\mathrm{pH}$ was adjusted to $\mathrm{pH} 6.5$ before planting using dolomitic lime (Lawn and Garden Lime; Sunniland Corp., Sanford, FL) at the recommended rate based on results of the Adams-Evans lime requirement test (Mylavarapu, 2009).

Forty-five plants of each species were transplanted on 30 June 2008. All species except caladium were transplanted from containers into clusters randomly planted within each raised landscape bed. Caladium tubers were planted directly into the landscape plots. Each plant cluster contained three plants of the same species forming a triangle with $\mathrm{l}-\mathrm{ft}$ spacing between individual plants. A total of three clusters per species were planted in each treatment plot. Controlledrelease fertilizer was applied at annual $\mathrm{N}$ rates of $0,2,4,6$, and $12 \mathrm{lb} / 1000$ $\mathrm{ft}^{2}$; $\mathrm{N}$ rates were based on the current Florida Friendly Landscaping ${ }^{\mathrm{TM}}$ Program recommendations for landscape fertilization (Florida Department of Environmental Protection, 2010). From 30 June 2008 through 17 Aug. 2009 (60 WAP), a polymer-coated ammonium sulfate fertilizer $(21 \mathrm{~N}-0 \mathrm{P}-$ 0K-24S; Honeywell nylon, Seffner, FL) was applied every 6 weeks based on the estimated release rate of the fertilizer as determine by 1 - and 7-d dissolution tests that were conducted on $10 \%$ weight/volume at 74 to $76^{\circ} \mathrm{F}$. In 2009, Honeywell discontinued production of the polymer-coated ammonium sulfate fertilizer. As a result, perennials were fertilized every 12 weeks with a $42 \mathrm{~N}-0 \mathrm{P}-0 \mathrm{~K}$ polymer-coated urea fertilizer (Polyon; Harrell's, Lakeland, FL) containing 33.6\% slowrelease $\mathrm{N}$ at the same $\mathrm{N}$ rates from 17 Aug. 2009 to 27 Apr. 2010 (60 to $96 \mathrm{WAP})$. The fertilization frequency for the polymer-coated urea fertilizer was based on the release rate curve supplied by the manufacturer.

The landscape beds remained unmulched to reduce the amount of nonfertilizer derived $\mathrm{N}$ available to growing plants. Other macronutrients
Table 1. Regression derived optimum and annual nitrogen $(\mathrm{N})$ rates for size index and plant tissue chlorophyll (SPAD) for selected landscape-grown perennial species based on plant response to fertilizer $\mathbf{N}$ rate when planted in late June (30 June 2008) in St. Augustine fine sand subsoil in U.S. Department of Agriculture hardiness zone 9a.

\begin{tabular}{|c|c|c|}
\hline \multirow{2}{*}{$\begin{array}{l}\text { Species and time } \\
\text { after planting (wk) }\end{array}$} & \multicolumn{2}{|c|}{$\begin{array}{l}\text { Optimum annual fertilizer } \\
\mathrm{N} \text { rate }\left(\mathrm{lb} / 1000 \mathrm{ft}^{2}\right)^{\mathrm{z}}\end{array}$} \\
\hline & Size index ${ }^{y}$ & SPAD \\
\hline \multicolumn{3}{|l|}{ Bush daisy } \\
\hline 6 & $>12$ & $>12$ \\
\hline 12 & $\mathrm{NS}^{\mathrm{x}}$ & $>12$ \\
\hline 18 & NS & $>12$ \\
\hline 24 & 9.4 & $>12$ \\
\hline 30 & 9.2 & $>12$ \\
\hline 36 & 8.9 & 7.3 \\
\hline 42 & 9.3 & 10.1 \\
\hline 48 & 9.6 & $>12$ \\
\hline 54 & 8.8 & $>12$ \\
\hline 60 & 9.5 & NS \\
\hline 66 & 10.3 & NS \\
\hline 72 & 10.3 & $>12$ \\
\hline 78 & 10.6 & NS \\
\hline 84 & 11.0 & NS \\
\hline 90 & 11.2 & $>12$ \\
\hline 96 & $>12$ & $>12$ \\
\hline \multicolumn{3}{|l|}{ Caladium } \\
\hline 6 & NS & - \\
\hline 12 & $>12$ & - \\
\hline 18 & $>12$ & - \\
\hline 24 & $-^{\mathrm{w}}$ & - \\
\hline 30 & - & - \\
\hline 36 & - & - \\
\hline 42 & - & - \\
\hline 48 & 7.6 & - \\
\hline 54 & NS & - \\
\hline 60 & $>12$ & - \\
\hline 66 & 8.8 & - \\
\hline 72 & $>12$ & - \\
\hline 78 & $>12$ & - \\
\hline 84 & - & - \\
\hline 90 & - & - \\
\hline 96 & - & - \\
\hline \multicolumn{3}{|l|}{ Lantana } \\
\hline 6 & $>12$ & NS \\
\hline 12 & 12.5 & NS \\
\hline 18 & $>12$ & $>12$ \\
\hline 24 & $>12$ & $>12$ \\
\hline 30 & $>12$ & NS \\
\hline 36 & $>12$ & NS \\
\hline 42 & $>12$ & $>12$ \\
\hline 48 & 9.6 & $>12$ \\
\hline 54 & - & - \\
\hline 60 & - & - \\
\hline 66 & NS & $>12$ \\
\hline 72 & $>12$ & NS \\
\hline 78 & $>12$ & $>12$ \\
\hline 84 & NS & - \\
\hline 90 & NS & - \\
\hline 96 & NS & $>12$ \\
\hline
\end{tabular}


Table 1. (Continued) Regression derived optimum and annual nitrogen (N) rates for size index and plant tissue chlorophyll (SPAD) for selected landscapegrown perennial species based on plant response to fertilizer $\mathrm{N}$ rate when planted in late June (30 June 2008) in St. Augustine fine sand subsoil in U.S. Department of Agriculture hardiness zone 9a.

\begin{tabular}{|c|c|c|}
\hline \multirow{2}{*}{$\begin{array}{l}\text { Species and time } \\
\text { after planting (wk) }\end{array}$} & \multicolumn{2}{|c|}{$\begin{array}{l}\text { Optimum annual fertilizer } \\
\mathrm{N} \text { rate }\left(1 \mathrm{~b} / 1000 \mathrm{ft}^{2}\right)^{\mathrm{z}}\end{array}$} \\
\hline & Size index ${ }^{y}$ & SPAD \\
\hline \multicolumn{3}{|l|}{ Liriope } \\
\hline 6 & NS & NS \\
\hline 12 & - & $>12$ \\
\hline 18 & - & NS \\
\hline 24 & NS & NS \\
\hline 30 & NS & $>12$ \\
\hline 36 & $>12$ & 11.8 \\
\hline 42 & $>12$ & 12.4 \\
\hline 48 & $>12$ & 13.7 \\
\hline 54 & $>12$ & $>12$ \\
\hline 60 & $>12$ & 11.6 \\
\hline 66 & $>12$ & $>12$ \\
\hline 72 & $>12$ & $>12$ \\
\hline 78 & NS & $>12$ \\
\hline 84 & $>12$ & 9.8 \\
\hline 90 & $>12$ & 10.6 \\
\hline 96 & $>12$ & $>12$ \\
\hline \multicolumn{3}{|l|}{ Salvia } \\
\hline 6 & $>12$ & $>12$ \\
\hline 12 & 9.2 & $>12$ \\
\hline 18 & 11.0 & NS \\
\hline 24 & $>12$ & NS \\
\hline 30 & $>12$ & $>12$ \\
\hline 36 & $>12$ & $>12$ \\
\hline 42 & 10.4 & $>12$ \\
\hline 48 & $>12$ & 3.4 \\
\hline 54 & 10.0 & $>12$ \\
\hline 60 & 7.9 & NS \\
\hline 66 & 8.1 & $>12$ \\
\hline 72 & 8.7 & $>12$ \\
\hline 78 & NS & NS \\
\hline 84 & NS & NS \\
\hline 90 & NS & $>12$ \\
\hline 96 & NS & $>12$ \\
\hline
\end{tabular}

${ }^{2}$ Optimum N rate for the 96 -week study period was determined for each regression fit by solving the second-order derivative of the equation to determine the maximum point on the regression curve. For linear (first-order) fits, the "optimum" $\mathrm{N}$ rate exceeded our fertilizer $\mathrm{N}$ rate and is reported as $>12 ; \mathrm{l} \mathrm{lb} / \mathrm{l} 000 \mathrm{ft}^{2}=48.8243 \mathrm{~kg} \cdot \mathrm{ha}^{-1}$.

y Size index was calculated as follows: SI (cubic centimeters) $=\mathrm{H} \times \mathrm{Wl} \times \mathrm{W} 2$, where $\mathrm{H}$ is the plant height (centimeters), W1 is the widest width of the plant (centimeters), and W2 is the width perpendicular to the widest width (centimeters); $1 \mathrm{~cm}^{3}=0.0610$ inch $^{3}, \mathrm{l} \mathrm{cm}=2.54 \mathrm{~cm}$

${ }^{\mathrm{x}} \mathrm{NS}=$ regression analysis was not significant.

w- = data not available.

and micronutrients were applied at the same rate to all plots according to UFIFAS recommendations (Kidder et al., 2009) based on results of the soil test. Soil test results indicated that no $\mathrm{P}$ fertilizer was required. We applied potassium sulfate fertilizer $(0 \mathrm{~N}-0 \mathrm{P}-$ 41.5K; Great Salt Lake Minerals Corp., Overland Park, KS) every four months at a $\mathrm{K}$ rate of $4.6 \mathrm{lb} / 1000 \mathrm{ft}^{2}$ per year (Kidder et al., 2009). As a preventative measure, a micronutrient fertilizer containing $\mathrm{S}, \mathrm{B}, \mathrm{Cu}, \mathrm{Fe}$, $\mathrm{Mn}, \mathrm{Mo}$, and $\mathrm{Zn}\left(\right.$ MicroMax $^{\circledR}$; Scotts, Marysville, $\mathrm{OH}$ ) was applied to all plots on 23 July 2009 at the label recommended rate.

Nine drip lines (Jain Irrigation, Winter Haven, FL) per bed were installed 1 -ft apart with 8 -inch spacing between emitters to supply irrigation to growing plants. Beds were irrigated starting at $0830 \mathrm{HR}$ for $25 \mathrm{~min}$, three times per week at a flow rate of $1 \mathrm{~L}$ per minute to apply a total of $1.80 \mathrm{~cm}$ of water per bed $\left(400 \mathrm{ft}^{2}\right)$. Cumulative rainfall and irrigation was 209.7 inches from 20 June 2008 to 27 Apr. 2010 (UF, 2010). Weeds were removed by hand or spot treated with glyphosate (Round-Up ${ }^{\circledR}$; Monsanto, Creve Coeur, MO).

Plant SI AND SHOOT DRY WEIGHT. SI was determined as a quantitative indicator of plant size based on measurements that were taken at planting and every six weeks over the 96week study period. SI was calculated as follows: SI (cubic centimeters) $=\mathrm{H} \times$ $\mathrm{W} 1 \times \mathrm{W} 2$, where $\mathrm{H}$ is the plant height (centimeters), $\mathrm{Wl}$ is the widest width of the plant (centimeters), and W2 is the width perpendicular to the widest width (centimeters). Aboveground plant tissue (i.e., shoots and stems) was removed at the soil surface at $96 \mathrm{WAP}$, dried to a constant weight at $40.5^{\circ} \mathrm{C}$, and weighed to determine shoot dry weight (grams).

Plant Chlorophyll CONTENT (SPAD). A portable chlorophyll meter (SPAD-502; Minolta Corp., Ramsey, NJ) was used to estimate plant chlorophyll content every 6 weeks for bush daisy, lantana, salvia, and liriope. Six SPAD readings (unitless) were taken on mature leaves per plant cluster (two readings per plant) and averaged. Fisher et al. (2003) found a linear relationship between SPAD and chlorophyll content $(0.2128+0.0295 \times$ SPAD; $\left.r^{2}=0.86\right)$ and suggested that SPAD was an indirect, but accurate predictor of chlorophyll content.

Plant tissue TKN analysis. Following measurement of shoot dry weight (96 WAP), the youngest, fully expanded leaves were collected from each of the harvested plants. Tissue samples were ground using a Wiley mill (Arthur H. Thomas Co., Philadelphia, PA), passed through a no. 20 screen, and dried at $110^{\circ} \mathrm{C}$ for $7 \mathrm{~d}$. Acid $(6 \mathrm{M} \mathrm{HCl})$ tissue digestions were completed using the standard methods of the UF-IFAS Extension Soil Testing Laboratory (Mylavarapu, 2009). Digested samples were analyzed for TKN on an Alpkem Technicon autoanalyzer (Pulse Instrumentation, Saskatoon, SK, Canada) using EPA Method 351.2 (USEPA, 1993c).

FLOWER Cover. Flower cover response to $\mathrm{N}$ fertilizer rate was determined for bush daisy, lantana, and salvia following the methods outlined in Shurberg et al. (2012). Overhead 
photographs of each plant cluster were taken every 6 weeks from 42 WAP through the end of the study (96 WAP). The brightness of the photos was adjusted to enhance color contrasts and the photographs were cropped to remove soil areas that did not contain plants using Photoshop Elements 6.0 (Adobe Systems, San Jose, CA). Specific color groups were assigned to represent flowers (color based on species), foliage (green), and soil background (brown). Computer image analysis (WinFOLIA 2007b for leaf analysis; Regent Instruments, Quebec, QC, Canada) was used to assign pixels in each photograph to one of the three color groups. The percent area covered by each color group was calculated by WINFOLIA based on pixel color. Flower cover was calculated as: flower cover $(\%)=$ flower area $\div$ (flower area + canopy area) $\times 100$, where flower area is the area (square centimeters) of the plant covered by flowers and canopy area is the area (square centimeters) of the plant covered only by canopy.

Plant visual Quality ratings. Aesthetic quality ratings were determined visually for each plant cluster at six week intervals. Quality ratings for each cluster considered canopy density, flowers, chlorosis, and dieback using the following scale: $0=$ dead plant(s), l = poor quality (low canopy density, few-no flowers, and chlorosis), 2 = below average quality (significant dieback), $3=$ average quality (moderate dieback), $4=$ above average quality (minimal dieback), and $5=$ outstanding plant quality (dense leaf canopy, high-quality flowers, and no nutrient deficiencies or dieback) (Shober et al., 2009a).

Statistical analysis. The experiment was laid out in a randomized complete block design with 15 blocks (landscape beds). Five $\mathrm{N}$ fertilizer rates were randomly applied over three clusters of five perennial species per landscape bed. Plant SI, SPAD, harvest biomass, and tissue TKN measurements were averaged for all plant clusters in each plot for each species. Mean values were then used in regression analysis using PROC REG (SAS version 9.2; SAS Institute, Cary, NC) to determine the effect of annual fertilizer $\mathrm{N}$ rate on each plant response indicator. Linear and polynomial regression models were fitted by species and WAP with $\mathrm{N}$ rate and $\mathrm{N}$ rate $\times \mathrm{N}$

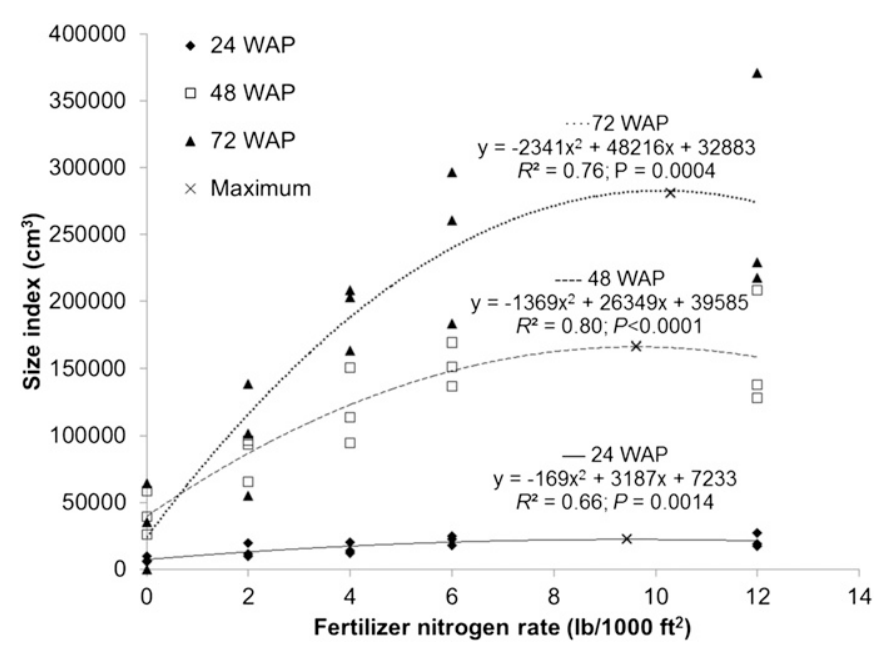

Fig. 1. Bush daisy size index response to fertilizer nitrogen $(\mathrm{N})$ rate at 24,28 , and 72 weeks after planting (WAP) when planted in St. Augustine fine sand subsoil fill in U.S. Department of Agriculture hardiness zone 9a. Regression analysis indicated second-order polynomial response with a maximum size at 24,48 , and 72 WAP was achieved when fertilizer $\mathrm{N}$ rate was $9.43,9.62$, and $10.30 \mathrm{lb} / 1000 \mathrm{ft}^{2}$, respectively; $1 \mathrm{~cm}^{3}=0.0610$ inches ${ }^{3}, 1 \mathrm{lb} / 1000 \mathrm{ft}^{2}=48.8243 \mathrm{~kg} \cdot \mathrm{ha}^{-1}$.

rate as the predictor variables. Regression analysis was considered significant if the probability value of the overall $\mathrm{F}$ test of the whole regression model and the fixed variables was $P \leq$ 0.05 . The second-order regression model was selected in favor of the linear regression model only when significance of the $\mathrm{N}$ rate $\times \mathrm{N}$ rate term $(P \leq 0.05)$ was indicated by a $t$ test. For each second-order regression fit, the second-order derivative of the equation was solved to determine the maximum point on the regression curve. The maximum point on the second-order regression curve corresponded to the "optimum" N rate for the specific plant response, or the point at which application of fertilizer $\mathrm{N}$ at higher rates was not expected to result in an increase in the mean plant response. When a linear (first-order) regression model provided the best fit, we could not determine the "optimum" $\mathrm{N}$ rate because it exceeded our maximum annual fertilizer $\mathrm{N}$ rate of $12 \mathrm{lb} / 1000 \mathrm{ft}^{2}$. Flower cover was analyzed by species and WAP using a linear mixed effects model for a randomized complete block design (PROC MIXED, SAS version 9.2) with fertilizer $\mathrm{N}$ rate as a fixed effect and plant cluster $\times$ treatment as a random effect. Plant quality data were analyzed by species and WAP using a general linear mixed effects model for a randomized complete block design (PROC GLIMMIX, SAS version 9.2)
Table 2. Regression derived optimum annual nitrogen $(\mathrm{N})$ rates for shoot biomass and tissue total Kjehldal $\mathbf{N}$ concentration for selected landscapegrown perennial species based on plant response to fertilizer $\mathrm{N}$ rate at 96 weeks after planting in late June (30 June 2008) in St. Augustine fine sand subsoil in U.S. Department of Agriculture hardiness zone 9a.

\begin{tabular}{|c|c|c|}
\hline \multirow[b]{2}{*}{ Species } & \multicolumn{2}{|c|}{$\begin{array}{c}\text { Optimum annual } \\
\text { fertilizer } N \text { rate } \\
\left(1 \mathrm{~b} / 1000 \mathrm{ft}^{2}\right)^{\mathrm{z}}\end{array}$} \\
\hline & $\begin{array}{c}\text { Shoot } \\
\text { biomass }\end{array}$ & $\begin{array}{c}\text { Total } \\
\text { Kjeldahl N } \\
\end{array}$ \\
\hline Bush daisy & 12.1 & $>12$ \\
\hline Caladium & $-^{\mathrm{y}}$ & $\mathrm{NS}^{\mathrm{x}}$ \\
\hline Lantana & $>12$ & $>12$ \\
\hline Liriope & $>12$ & 17 \\
\hline Salvia & 8.57 & $>12$ \\
\hline \multicolumn{3}{|c|}{$\begin{array}{l}{ }^{2} \text { Optimum } \mathrm{N} \text { rate for the } 96 \text {-week study period was } \\
\text { determined for each regression fit by solving the } \\
\text { second-order derivative of the equation to determine } \\
\text { the maximum point on the regression curve. For } \\
\text { linear (first-order) fits, the "optimum" } \mathrm{N} \text { rate } \\
\text { exceeded our fertilizer } \mathrm{N} \text { rate and is reported as }>12 \text {; } \\
1 \mathrm{lb} / 1000 \mathrm{ft}^{2}=48.8243 \mathrm{~kg} \cdot \mathrm{ha}^{-1} \text {. } \\
\mathrm{y}_{-}=\text {data not available. }\end{array}$} \\
\hline
\end{tabular}

with $\mathrm{N}$ rate as a fixed effect and treatment $\times$ cluster as a random effect (normal distribution and an identity link function). Pairwise comparisons for flower cover and quality were completed using the Tukey's honestly significant difference test with a significance level of $\alpha=0.05$. All data were checked for normality by examining 
Table 3. Flower cover mean response of selected landscape-grown perennial species to fertilizer nitrogen (N) rate when planted in late June (30 June 2008) in St. Augustine fine sand subsoil in U.S. Department of Agriculture hardiness zone 9a.

\begin{tabular}{|c|c|c|c|c|c|c|c|}
\hline \multirow{2}{*}{$\begin{array}{l}\text { Species and annual fertilizer } \\
\mathrm{N} \text { rate }\left(\mathrm{lb} / 1000 \mathrm{ft}^{2}\right)^{\mathrm{z}}\end{array}$} & \multicolumn{7}{|c|}{ Flower cover $(\%)^{y}$} \\
\hline & $42 \mathrm{WAP}^{\mathrm{x}}$ & $48 \mathrm{WAP}$ & 54 WAP & $60 \mathrm{WAP}$ & $66 \mathrm{WAP}$ & $72 \mathrm{WAP}$ & $78 \mathrm{WAP}$ \\
\hline \multicolumn{8}{|l|}{ Bush daisy } \\
\hline 2 & $8.16 \mathrm{a}$ & $4.74 \mathrm{c}$ & 0.89 & 3.24 & 1.73 & $0.61 \mathrm{~b}$ & 6.77 \\
\hline 4 & $10.5 \mathrm{a}$ & $10.4 \mathrm{~b}$ & 0.97 & 2.19 & 2.66 & $1.75 \mathrm{~b}$ & 9.10 \\
\hline 6 & $14.8 \mathrm{a}$ & $14.8 \mathrm{a}$ & 1.24 & 1.47 & 3.40 & $2.63 \mathrm{ab}$ & 11.24 \\
\hline 0 & 19.7 & $11.5 \mathrm{a}$ & $一^{\mathrm{v}}$ & $6.79 \mathrm{ab}$ & $7.19 \mathrm{a}$ & 1.40 & 2.35 \\
\hline 2 & 22.5 & $11.4 \mathrm{ab}$ & - & $6.96 \mathrm{a}$ & $5.71 \mathrm{ab}$ & 1.57 & 2.38 \\
\hline 4 & 21.5 & $10.9 \mathrm{ab}$ & - & $5.18 \mathrm{~b}$ & $6.28 \mathrm{ab}$ & 1.65 & 1.61 \\
\hline 6 & 22.8 & $11.5 \mathrm{ab}$ & - & $5.78 \mathrm{ab}$ & $5.46 \mathrm{ab}$ & 1.91 & 2.61 \\
\hline 12 & 21.3 & $8.6 \mathrm{~b}$ & - & $6.24 \mathrm{ab}$ & $4.56 \mathrm{~b}$ & 2.00 & 2.42 \\
\hline 6 & 30.4 & 33.8 & $22.9 \mathrm{abc}$ & $41.0 \mathrm{ab}$ & $18.2 \mathrm{c}$ & 35.1 & 6.15 \\
\hline 12 & 29.2 & 27.3 & $20.0 \mathrm{bc}$ & $44.0 \mathrm{a}$ & $22.5 \mathrm{bc}$ & 26.3 & 5.29 \\
\hline
\end{tabular}

${ }^{2} 1 \mathrm{lb} / 1000 \mathrm{ft}^{2}=48.8243 \mathrm{~kg} \cdot \mathrm{ha}^{-1}$.

'Flower cover $=$ flower area $\div$ (flower area + canopy area $) \times 100$.

${ }^{x} \mathrm{WAP}=$ week after planting.

wean separation across $\mathrm{N}$ fertilizer treatments for each species and WAP was conducted by Tukey's honestly significant difference test at $P<0.05$.

- = data not available.

histogram and normality plots of the Studentized residuals.

\section{Results}

Plant SI AND SHOOT DRY WEIGHT. At most sampling dates, a significant plant SI response to fertilizer $\mathrm{N}$ rate was reported for all plant species (Table 1 ). In general, the relationship between plant SI and $\mathrm{N}$ fertilizer rate was best explained by a second-order polynomial regression for bush daisy (Fig. 1, Table 1) and salvia (Table 1). Therefore, we were able to estimate the $\mathrm{N}$ fertilizer rate above which no plant SI increase was expected for bush daisy (Fig. 1) and salvia at most sampling dates. Based on regression analysis, we suggest that bush daisy and salvia required $\mathrm{N}$ fertilizer applications in excess of 8 $\mathrm{lb} / 1000 \mathrm{ft}^{2}$ per year to achieve maximum size. In contrast, a first-order relationship between SI and $\mathrm{N}$ rate was typically reported for caladium, lantana, and liriope at most sampling dates (Table 1 ). These results suggested that annual applications of $\mathrm{N}$ fertilizer of up to $12 \mathrm{lb} / 1000 \mathrm{ft}^{2}$ were too low to maximize SI for caladium, lantana, or liriope in most weeks (Table 1). However, it is important to note that caladium SI data were unavailable at several sampling dates because of multiple periods of plant dormancy (Table 1).

Trends for dry shoot weight were similar to SI data trends, where the biomass response to $\mathrm{N}$ fertilizer rate was best described by a second-order polynomial equation for bush daisy and salvia. Dry biomass was predicted for bush daisy and salvia at an annual $\mathrm{N}$ fertilizer rate of 12 and $8.6 \mathrm{lb} / 1000 \mathrm{ft}^{2}$, respectively (Table 2 ). There was a linear relationship between shoot weight and $\mathrm{N}$ rate for lantana and liriope, suggesting that the annual fertilizer $\mathrm{N}$ applications in excess of $12 \mathrm{lb} / 1000$ $\mathrm{ft}^{2}$ were needed to produce lantana and liriope of maximum attainable biomass (Table 2). Dry shoot weight was not determined for caladium because of plant dormancy at the time of harvest (data not shown).

Plant CHLOROPHYLL CONTENT (SPAD). At most sampling dates, a significant positive relationship existed between plant SPAD meter readings (proxy for chlorophyll content) and $\mathrm{N}$ fertilizer rate for all species (Table $\mathrm{l}$ ). Chlorophyll data (SPAD) for bush daisy, lantana, and salvia were best fit by a first-order regression during most weeks, indicating that plants did not achieve maximum SPAD even when fertilized at the $12 \mathrm{lb} / 1000 \mathrm{ft}^{2}$ annual $\mathrm{N}$ rate. For liriope SPAD readings, the best fitting regression model varied between a first-order regression (12, $3054,66,72,78$, and $96 \mathrm{WAP}$ ) and a second-order polynomial $(36,42$, $48,60,84$, and 90 WAP) over the course of the study. A significant linear regression model suggested that the lowest rate at which chlorophyll content of liriope was maximized was an $\mathrm{N}$ application rate of $9.8 \mathrm{lb} / 1000 \mathrm{ft}^{2}$ per year (Table 1).

Plant tissue TKN analysis. A significant first-order relationship was reported between plant tissue TKN and $\mathrm{N}$ fertilizer rate for bush daisy, lantana, and salvia (Table 2). These data again supports the need for $\mathrm{N}$ fertilizer applications at rates higher than $12 \mathrm{lb} / 1000 \mathrm{ft}^{2}$ to achieve maximum tissue TKN. Only liriope TKN exhibited a significant second-order relationship with fertilizer $\mathrm{N}$ rate, with maximum tissue TKN predicted at an annual $\mathrm{N}$ rate of 17 $\mathrm{lb} / 1000 \mathrm{ft}^{2}$ (Table 2). Neither regression model explained the relationship between caladium tissue TKN and fertilizer $\mathrm{N}$ rate; this was probably due to collection of tissue during plant decline before a dormancy period.

Flower COVER. Flower cover response to $\mathrm{N}$ fertilizer was observed for bush daisy at 42,48 , and 78 WAP 
Table 4. Aesthetic quality of selected landscape-grown perennial species to fertilizer nitrogen $(N)$ rate when planted in late June (30 June 2008) in St. Augustine fine sand subsoil fill in U.S. Department of Agriculture hardiness zone 9a.

\begin{tabular}{|c|c|c|c|c|c|}
\hline \multirow{2}{*}{$\begin{array}{l}\text { Time after planting } \\
\text { and annual fertilizer } \\
\mathrm{N} \text { rate }\left(\mathrm{lb} / 1000 \mathrm{ft}^{2}\right)^{\mathrm{z}}\end{array}$} & \multicolumn{5}{|c|}{ Plant aesthetic quality (0-5 scale $)^{\mathrm{y}}$} \\
\hline & Bush daisy & Caladium & Liriope & Lantana & Salvia \\
\hline \multicolumn{6}{|l|}{$6 \mathrm{WAP}^{\mathrm{x}}$} \\
\hline 0 & $1.9 c^{w}$ & 2.2 & 3.2 & $1.9 \mathrm{c}$ & $1.1 \mathrm{c}$ \\
\hline 2 & $2.1 \mathrm{bc}$ & 2.0 & 2.9 & $1.9 \mathrm{c}$ & $1.3 \mathrm{bc}$ \\
\hline 4 & $2.3 \mathrm{bc}$ & 2.4 & 3.0 & $2.5 \mathrm{bc}$ & $1.6 \mathrm{bc}$ \\
\hline 6 & $2.5 \mathrm{ab}$ & 2.4 & 2.9 & $2.8 \mathrm{~b}$ & $1.9 \mathrm{~b}$ \\
\hline 12 & $3.0 \mathrm{a}$ & 2.1 & 3.4 & $3.7 \mathrm{a}$ & $3.1 \mathrm{a}$ \\
\hline \multicolumn{6}{|l|}{$12 \mathrm{WAP}$} \\
\hline 0 & $1.7 \mathrm{c}$ & $1.8 \mathrm{~b}$ & 3.1 & $3.0 \mathrm{c}$ & $1.1 \mathrm{~b}$ \\
\hline 2 & $2.6 \mathrm{~b}$ & $2.5 \mathrm{a}$ & 3.0 & $3.2 \mathrm{bc}$ & $1.4 \mathrm{~b}$ \\
\hline 4 & $3.6 \mathrm{a}$ & $2.7 \mathrm{a}$ & 3.1 & $3.8 \mathrm{~b}$ & $2.4 \mathrm{a}$ \\
\hline 6 & $3.3 \mathrm{ab}$ & $2.9 \mathrm{a}$ & 2.6 & $3.9 \mathrm{~b}$ & $3.0 \mathrm{a}$ \\
\hline 12 & $3.5 \mathrm{ab}$ & $2.7 \mathrm{a}$ & 2.6 & $4.9 \mathrm{a}$ & $3.0 \mathrm{a}$ \\
\hline \multicolumn{6}{|l|}{$18 \mathrm{WAP}$} \\
\hline 0 & $2.0 \mathrm{~b}$ & $2.3 \mathrm{~b}$ & 3.3 & $3.1 \mathrm{c}$ & $1.0 \mathrm{~b}$ \\
\hline 2 & $3.1 \mathrm{a}$ & $3.2 \mathrm{a}$ & 3.1 & $4.3 \mathrm{~b}$ & $1.5 \mathrm{~b}$ \\
\hline 4 & $4.0 \mathrm{a}$ & $2.9 \mathrm{ab}$ & 3.6 & $4.9 \mathrm{a}$ & $2.4 \mathrm{a}$ \\
\hline 6 & $4.0 \mathrm{a}$ & $2.8 \mathrm{ab}$ & 3.1 & $4.9 \mathrm{a}$ & $2.2 \mathrm{a}$ \\
\hline 12 & $3.8 \mathrm{a}$ & $3.2 \mathrm{a}$ & 3.6 & $5.0 \mathrm{a}$ & $2.7 \mathrm{a}$ \\
\hline \multicolumn{6}{|l|}{24 WAP } \\
\hline 0 & $1.5 \mathrm{c}$ & $一^{\mathrm{v}}$ & 3.0 & $2.7 \mathrm{~d}$ & $1.1 \mathrm{~d}$ \\
\hline 2 & $2.7 \mathrm{~b}$ & - & 3.1 & $3.2 \mathrm{~cd}$ & $2.0 \mathrm{c}$ \\
\hline 4 & $3.4 \mathrm{ab}$ & - & 3.4 & $3.7 \mathrm{bc}$ & $3.1 \mathrm{~b}$ \\
\hline 6 & $3.8 \mathrm{a}$ & - & 3.0 & $3.9 \mathrm{~b}$ & $3.4 \mathrm{ab}$ \\
\hline 12 & $4.0 \mathrm{a}$ & - & 3.5 & $4.9 \mathrm{a}$ & $4.0 \mathrm{a}$ \\
\hline \multicolumn{6}{|l|}{$30 \mathrm{WAP}$} \\
\hline 0 & $1.1 \mathrm{c}$ & - & 3.0 & $2.2 \mathrm{c}$ & $1.0 \mathrm{c}$ \\
\hline 2 & $2.4 \mathrm{~b}$ & - & 3.2 & $2.9 \mathrm{bc}$ & $1.6 \mathrm{c}$ \\
\hline 4 & $3.5 \mathrm{a}$ & - & 3.3 & $3.6 \mathrm{ab}$ & $2.8 \mathrm{~b}$ \\
\hline 6 & $3.3 \mathrm{a}$ & - & 2.9 & $3.0 \mathrm{~b}$ & $2.9 \mathrm{~b}$ \\
\hline 12 & $3.4 \mathrm{a}$ & - & 3.3 & $4.2 \mathrm{a}$ & $3.7 \mathrm{a}$ \\
\hline \multicolumn{6}{|l|}{$36 \mathrm{WAP}$} \\
\hline 0 & $1.0 \mathrm{c}$ & - & $2.8 \mathrm{~b}$ & $1.1 \mathrm{~b}$ & $1.0 \mathrm{c}$ \\
\hline 2 & $1.9 \mathrm{~b}$ & - & $3.2 \mathrm{ab}$ & $1.2 \mathrm{ab}$ & $1.5 \mathrm{c}$ \\
\hline 4 & $3.0 \mathrm{a}$ & - & $3.2 \mathrm{ab}$ & $1.3 \mathrm{ab}$ & $2.4 \mathrm{~b}$ \\
\hline 6 & $2.9 \mathrm{a}$ & - & $3.2 \mathrm{ab}$ & $1.4 \mathrm{ab}$ & $2.7 \mathrm{ab}$ \\
\hline 12 & $2.8 \mathrm{a}$ & - & $3.6 \mathrm{a}$ & $1.8 \mathrm{a}$ & $3.1 \mathrm{a}$ \\
\hline \multicolumn{6}{|l|}{42 WAP } \\
\hline 0 & $1.6 \mathrm{c}$ & - & $3.0 \mathrm{~b}$ & $3.1 \mathrm{~d}$ & $1.0 \mathrm{c}$ \\
\hline 2 & $2.5 \mathrm{~b}$ & - & $3.3 \mathrm{ab}$ & $3.8 \mathrm{c}$ & $2.0 \mathrm{~b}$ \\
\hline 4 & $3.3 \mathrm{a}$ & - & $3.9 \mathrm{a}$ & $4.6 \mathrm{ab}$ & $3.6 \mathrm{a}$ \\
\hline 6 & $3.6 \mathrm{a}$ & - & $3.4 \mathrm{ab}$ & $4.3 \mathrm{bc}$ & $3.6 \mathrm{a}$ \\
\hline 12 & $3.8 \mathrm{a}$ & - & $4.1 \mathrm{a}$ & $5.0 \mathrm{a}$ & $4.0 \mathrm{a}$ \\
\hline \multicolumn{6}{|l|}{48 WAP } \\
\hline 0 & $1.4 \mathrm{~d}$ & - & $2.9 \mathrm{~b}$ & $3.7 \mathrm{~b}$ & $1.2 \mathrm{c}$ \\
\hline 2 & $2.7 \mathrm{c}$ & - & $3.4 \mathrm{ab}$ & $4.6 \mathrm{a}$ & $1.9 \mathrm{c}$ \\
\hline 4 & $3.8 \mathrm{~b}$ & - & $3.6 \mathrm{ab}$ & $4.8 \mathrm{a}$ & $3.3 \mathrm{~b}$ \\
\hline 6 & $4.7 \mathrm{a}$ & - & $3.6 \mathrm{ab}$ & $4.7 \mathrm{a}$ & $4.1 \mathrm{a}$ \\
\hline 12 & $4.6 \mathrm{a}$ & - & $4.0 \mathrm{a}$ & $4.9 \mathrm{a}$ & $4.3 \mathrm{a}$ \\
\hline \multicolumn{6}{|l|}{54 WAP } \\
\hline 0 & $1.4 \mathrm{~d}$ & 2.4 & 3.1 & $3.1 \mathrm{c}$ & $1.1 \mathrm{c}$ \\
\hline 2 & $2.7 \mathrm{c}$ & 2.5 & 3.3 & $3.9 \mathrm{~b}$ & $1.9 \mathrm{~b}$ \\
\hline 4 & $3.3 \mathrm{bc}$ & 2.7 & 3.2 & $4.1 \mathrm{~b}$ & $3.0 \mathrm{a}$ \\
\hline 6 & $4.0 \mathrm{ab}$ & 3.1 & 3.2 & $4.4 \mathrm{ab}$ & $3.5 \mathrm{a}$ \\
\hline 12 & $4.4 \mathrm{a}$ & 2.8 & 3.4 & $4.9 \mathrm{a}$ & $3.6 \mathrm{a}$ \\
\hline
\end{tabular}

(Continued on next page)
(Table 3). At 42 WAP, plants receiving $\mathrm{N}$ fertilizer at the $2,4,6$, or $12 \mathrm{lb} / 1000 \mathrm{ft}^{2}$ annual rate had a higher proportion of the plant canopy covered with flowers than plants receiving no $\mathrm{N}$ fertilizer. At $48 \mathrm{WAP}$, bush daisy flower cover was highest for plants receiving fertilizer at the 6 and $12 \mathrm{lb} / 1000 \mathrm{ft}^{2}$ annual rate, followed by plants fertilized at the $4 \mathrm{lb} / 1000$ $\mathrm{ft}^{2}$ rate; bush daisy receiving 0 or 2 $\mathrm{lb} / 1000 \mathrm{ft}^{2}$ annual $\mathrm{N}$ rate had significantly less flower coverage than the plants receiving $\mathrm{N}$ at the higher rates (Table 3 ). At $72 \mathrm{WAP}$, only the 12 $\mathrm{lb} / 1000 \mathrm{ft}^{2}$ rate produced bush daisy plants with a higher proportion of flower coverage than plants fertilized at the 0,2 , or $4 \mathrm{lb} / 1000 \mathrm{ft}^{2}$ annual $\mathrm{N}$ rate. Fertilization had a significant effect on lantana flower coverage only at 48,60, and 66 WAP (Table $3)$. Lantana plants receiving $\mathrm{N}$ at the $12-\mathrm{lb} / 1000 \mathrm{ft}^{2}$ annual rate tended to have less flower coverage than unfertilized plants at 48 and 66 WAP. However, at $60 \mathrm{WAP}$, lantana receiving $4 \mathrm{lb} / 1000 \mathrm{ft}^{2} \mathrm{~N}$ had a lower proportion of flower coverage than plants receiving $2 \mathrm{lb} / 1000 \mathrm{ft}^{2} \mathrm{~N}$. Salvia flower coverage was affected by $\mathrm{N}$ fertilizer only at 54,60, and 66 WAP (Table 3). At 54 WAP, salvia plants receiving $\mathrm{N}$ fertilizer at the 2 $\mathrm{lb} / \mathrm{l} 000 \mathrm{ft}^{2}$ annual rate had the highest proportion of the plant canopy covered with flowers; at 66 WAP, flower cover was highest when salvia plants were supplied with fertilizer at the 0 or $2 \mathrm{lb} / 1000 \mathrm{ft}^{2}$ annual $\mathrm{N}$ rate. However, at $60 \mathrm{WAP}$, salvia plants receiving $\mathrm{N}$ fertilizer at the $12-\mathrm{lb} /$ $1000 \mathrm{ft}^{2}$ annual rate had a higher proportion of the plant canopy covered with flowers than those receiving no $\mathrm{N}$ fertilizer (Table 3 ). There were no differences in flower cover for any species after 78 WAP (data not shown). Overall, fertilizing perennial species with 2 to $4 \mathrm{lb} / 1000 \mathrm{ft}^{2} \mathrm{~N}$ annually should produce plants with acceptable flower coverage. We did not see evidence for increasing flower coverage at annual $\mathrm{N}$ application rates above $4 \mathrm{lb} / 1000 \mathrm{ft}^{2}$.

Plant visual Quality Ratings. The visual quality response of perennials to $\mathrm{N}$ fertilizer rate varied by species (Table 4). At $72 \mathrm{WAP}$, there were no significant differences in the visual quality of bush daisy when they were supplied with $\mathrm{N}$ at an annual rate of $2,4,6$, or $12 \mathrm{lb} / 1000 \mathrm{ft}^{2}$. 
Table 4. (Continued) Aesthetic quality of selected landscape-grown perennial species to fertilizer nitrogen $(N)$ rate when planted in late June (30 June 2008) in St. Augustine fine sand subsoil fill in U.S. Department of Agriculture hardiness zone 9a.

\begin{tabular}{|c|c|c|c|c|c|}
\hline \multirow{2}{*}{$\begin{array}{l}\text { Time after planting } \\
\text { and annual fertilizer } \\
\mathrm{N} \text { rate }\left(1 \mathrm{~b} / 1000 \mathrm{ft}^{2}\right)^{\mathrm{z}}\end{array}$} & \multicolumn{5}{|c|}{ Plant aesthetic quality ( $0-5$ scale $)^{y}$} \\
\hline & Bush daisy & Caladium & Liriope & Lantana & Salvia \\
\hline \multicolumn{6}{|l|}{60 WAP } \\
\hline 0 & $1.1 \mathrm{c}$ & $2.7 \mathrm{~b}$ & 2.8 & $3.8 \mathrm{~b}$ & $1.2 \mathrm{c}$ \\
\hline 2 & $2.1 \mathrm{~b}$ & $3.2 \mathrm{ab}$ & 3.3 & $3.9 \mathrm{ab}$ & $1.7 \mathrm{bc}$ \\
\hline 4 & $2.7 \mathrm{ab}$ & $3.3 \mathrm{ab}$ & 3.2 & $4.1 \mathrm{ab}$ & $2.2 \mathrm{ab}$ \\
\hline 6 & $2.7 \mathrm{ab}$ & $3.3 \mathrm{ab}$ & 3.4 & $4.0 \mathrm{ab}$ & $2.5 \mathrm{a}$ \\
\hline 12 & $3.4 \mathrm{a}$ & $3.4 \mathrm{a}$ & 3.6 & $4.3 \mathrm{a}$ & $2.0 \mathrm{ab}$ \\
\hline \multicolumn{6}{|l|}{66 WAP } \\
\hline 0 & $1.0 \mathrm{c}$ & 2.6 & 2.8 & 4.3 & $1.9 \mathrm{~b}$ \\
\hline 2 & $1.7 \mathrm{bc}$ & 2.9 & 3.4 & 4.0 & $2.3 \mathrm{ab}$ \\
\hline 4 & $2.1 \mathrm{ab}$ & 3.0 & 3.4 & 4.1 & $2.6 \mathrm{ab}$ \\
\hline 6 & $2.5 \mathrm{ab}$ & 2.8 & 3.4 & 3.8 & $2.9 \mathrm{a}$ \\
\hline 12 & $2.6 \mathrm{a}$ & 2.6 & 3.7 & 4.0 & $2.7 \mathrm{a}$ \\
\hline \multicolumn{6}{|l|}{72 WAP } \\
\hline 0 & $1.0 \mathrm{~b}$ & $1.6 \mathrm{~b}$ & 2.9 & 2.7 & 1.1 \\
\hline 2 & $1.4 \mathrm{ab}$ & $2.2 \mathrm{a}$ & 3.2 & 2.6 & 1.4 \\
\hline 4 & $1.9 \mathrm{ab}$ & $2.4 \mathrm{a}$ & 3.2 & 2.7 & 1.8 \\
\hline 6 & $2.4 \mathrm{a}$ & $2.3 \mathrm{a}$ & 3.0 & 2.4 & 1.8 \\
\hline 12 & $2.3 \mathrm{a}$ & $2.6 \mathrm{a}$ & 3.6 & 2.6 & 1.5 \\
\hline \multicolumn{6}{|l|}{78 WAP } \\
\hline 0 & $1.1 \mathrm{~b}$ & $1.3 \mathrm{~b}$ & 3.1 & 2.4 & 1.5 \\
\hline 2 & $1.7 \mathrm{ab}$ & $1.6 \mathrm{ab}$ & 3.8 & 2.4 & 1.4 \\
\hline 4 & $2.4 \mathrm{ab}$ & $1.4 \mathrm{ab}$ & 3.7 & 2.4 & 1.8 \\
\hline 6 & $2.9 \mathrm{a}$ & $1.8 \mathrm{ab}$ & 3.7 & 2.3 & 1.6 \\
\hline 12 & $2.9 \mathrm{a}$ & $2.1 \mathrm{a}$ & 3.9 & 2.6 & 1.4 \\
\hline \multicolumn{6}{|l|}{84 WAP } \\
\hline 0 & $1.2 \mathrm{~b}$ & - & 2.8 & - & 1.0 \\
\hline 2 & $1.4 \mathrm{~b}$ & - & 3.3 & - & 1.0 \\
\hline 4 & $2.0 \mathrm{ab}$ & - & 3.1 & - & 1.0 \\
\hline 6 & $2.3 \mathrm{a}$ & - & 3.0 & - & 1.1 \\
\hline 12 & $2.3 \mathrm{a}$ & - & 3.3 & - & 1.1 \\
\hline \multicolumn{6}{|l|}{90 WAP } \\
\hline 0 & $1.1 \mathrm{~b}$ & - & 2.8 & 1.1 & $1.3 \mathrm{~b}$ \\
\hline 2 & $1.5 \mathrm{~b}$ & - & 3.3 & 1.4 & $1.5 \mathrm{ab}$ \\
\hline 4 & $2.2 \mathrm{ab}$ & - & 3.1 & 1.3 & $2.0 \mathrm{a}$ \\
\hline 6 & $2.7 \mathrm{a}$ & - & 3.2 & 1.3 & $2.0 \mathrm{a}$ \\
\hline 12 & $3.1 \mathrm{a}$ & - & 3.8 & 1.7 & $1.8 \mathrm{ab}$ \\
\hline \multicolumn{6}{|l|}{96 WAP } \\
\hline 0 & $1.6 \mathrm{~b}$ & - & $3.0 \mathrm{~b}$ & 3.4 & $1.5 \mathrm{~b}$ \\
\hline 2 & $1.6 \mathrm{~b}$ & - & $3.6 \mathrm{ab}$ & 4.0 & $1.6 \mathrm{~b}$ \\
\hline 4 & $2.7 \mathrm{a}$ & - & $3.9 \mathrm{ab}$ & 4.0 & $2.4 \mathrm{ab}$ \\
\hline 6 & $3.1 \mathrm{a}$ & - & $3.8 \mathrm{ab}$ & 3.6 & $2.6 \mathrm{a}$ \\
\hline 12 & $3.3 \mathrm{a}$ & - & $4.3 \mathrm{a}$ & 3.9 & $2.6 \mathrm{a}$ \\
\hline
\end{tabular}

${ }^{2} \mathrm{llb} / 1000 \mathrm{ft}^{2}=48.8243 \mathrm{~kg} \cdot \mathrm{ha}^{-1}$

${ }^{y} 0=$ dead plant(s); 5 = outstanding plant quality (dense leaf canopy, high quality flowers, no nutrient deficiencies, no dieback).

${ }^{x} \mathrm{WAP}=$ week after planting

${ }^{w}$ Mean separation across N fertilizer treatments for each species and WAP was conducted by Tukey's honestly significant difference (HSD) test at $P<0.05$.

v $-=$ data not available.

However, the visual quality of bush daisy plants receiving fertilizer at the 4,6 , or $12 \mathrm{lb} / 1000 \mathrm{ft}^{2}$ annual $\mathrm{N}$ rate was greater than plants fertilized at the 0 or $2 \mathrm{lb} / 1000 \mathrm{ft}^{2}$ rate during most weeks (Fig. 2; Table 4). Bush daisy plants receiving 4,6 , or $12 \mathrm{lb} /$ $1000 \mathrm{ft}^{2} \mathrm{~N}$ in year one ( 12 to $48 \mathrm{WAP}$ ) produced plants with quality ratings of average (2.8) or better. Bush daisy plants in year two had slightly lower quality average ratings, than plants in year one, for those plants receiving 4, 6 , or $12 \mathrm{lb} / 1000 \mathrm{ft}^{2} \mathrm{~N}$ (Fig. 2; Table 4). Plant quality response to $\mathrm{N}$ fertilizer was only recorded for caladium from 6 to 18 WAP and from 54 to 78 WAP. Quality response of caladium could not be evaluated at other weeks when caladium plants were undergoing periods of dormancy. Caladium receiving fertilizer at rates of $2,4,6$, or $12 \mathrm{lb} / 1000 \mathrm{ft}^{2}$ at 12 and 72 WAP had significantly higher quality rates than plants receiving no fertilizer $(0 \mathrm{lb} /$ $1000 \mathrm{ft}^{2}$ per year). Caladium supplied with fertilizer at a rate of 2 or $12 \mathrm{lb} /$ $1000 \mathrm{ft}^{2} \mathrm{~N}$ produced higher quality plants than control treatments at 18 WAP; plants supplied with $12 \mathrm{lb} / 1000$ $\mathrm{ft}^{2}$ produced higher quality plants than control treatments at 60,72 , and 78 WAP. Nitrogen fertilizer treatment had no effect on caladium quality during any other weeks (Table 4). Similarly, the visual quality of liriope was only significantly affected by $\mathrm{N}$ fertilizer rate at $36,42,48$, and 96 WAP. At 36, 48, and 96 WAP, liriope quality was higher when fertilized with $12 \mathrm{lb} / 1000 \mathrm{ft}^{2} \mathrm{~N}$ per year than plants receiving $0 \mathrm{lb} / 1000$ $\mathrm{ft}^{2} \mathrm{~N}$ (Table 4). At $42 \mathrm{WAP}$, liriope quality was higher when fertilized at the 4 or $12 \mathrm{lb} / 1000 \mathrm{ft}^{2}$ annual $\mathrm{N}$ rate than plants receiving $0 \mathrm{lb} / 1000 \mathrm{ft}^{2} \mathrm{~N}$ (Table 4). All liriope plants receiving fertilizer at rates greater than $0 \mathrm{lb} /$ $1000 \mathrm{ft}^{2} \mathrm{~N}$ produced liriope with quality ratings of 2.9 (acceptable) or better regardless of treatment from 18 to 96 WAP.

Nitrogen rate influenced the visual quality of lantana mainly during the first year after planting (Table 4). Applications of $\mathrm{N}$ fertilizer at the 12 $\mathrm{lb} / 1000 \mathrm{ft}^{2}$ annual $\mathrm{N}$ rate produced higher quality plants than all other treatments during most weeks from 6 to 60 WAP (Table 4). However, nearly all treatments produced lantana that were rated 3 (acceptable) or better at all sampling dates with the exception of a decline in quality at $36 \mathrm{WAP}$ because of a period of cold temperatures. There was no $\mathrm{N}$ fertilizer rate effect on lantana quality from 66 WAP through the end of the study at 96 WAP (Table 4). Salvia quality was higher when fertilized at the annual $\mathrm{N}$ rate of 4,6 , or $12 \mathrm{lb} / 1000 \mathrm{ft}^{2} \mathrm{com}$ pared with all other treatments during most weeks from 12 to 54 WAP (Table 4). A fertilizer treatment of at least $4 \mathrm{lb} / 1000 \mathrm{ft}^{2} \mathrm{~N}$ was needed to 


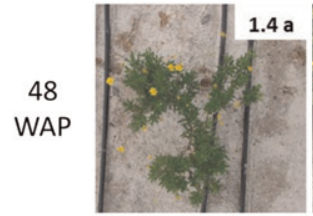

$0 \mathrm{lb} / 1000 \mathrm{ft}^{2}$

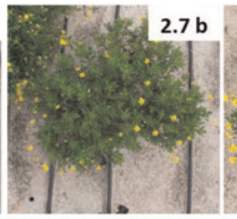

$2 \mathrm{lb} / 1000 \mathrm{ft}^{2}$

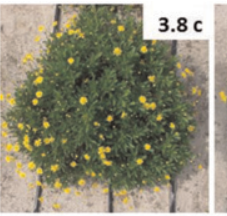

$4 \mathrm{lb} / 1000 \mathrm{ft}^{2}$

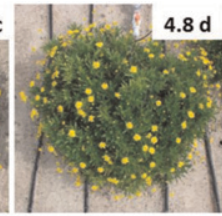

$6 \mathrm{lb} / 1000 \mathrm{ft}^{2}$

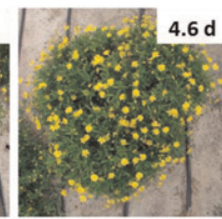

$12 \mathrm{lb} / 1000 \mathrm{ft}^{2}$
72

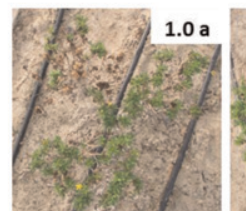

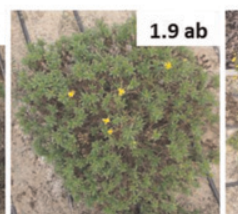

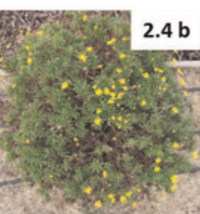

$2.4 \mathrm{~b}$

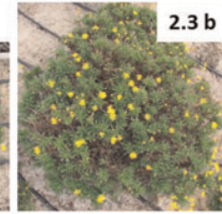

Fig. 2. Aesthetic quality response of bush daisy to fertilizer nitrogen rate at 48 and 72 weeks after planting (WAP) when planted in St. Augustine fine sand subsoil fill in U.S. Department of Agriculture hardiness zone 9a. Mean separation for species and WAP was conducted by Tukey's honestly significant difference test at $P \leq 0.05$; $1 \mathrm{lb} / 1000 \mathrm{ft}^{2}=48.8243 \mathrm{~kg} \cdot \mathrm{ha}^{-1}$.

produce salvia plant quality of 3 or better in year one, but all plants had a quality rating of less than 3 in year two (60-96 WAP), regardless of treatment. Both salvia and lantana needed less fertilizer to produce high quality plants in the second year of the study (Table 4).

\section{Discussion}

Similar to results reported for annual landscape plants (Shurberg et al., 2012) and other perennial species (Chen et al., 2011), plant fertilizer requirements varied by species. Also, the landscape herbaceous perennial species we evaluated generally required high rates of $\mathrm{N}$ (often in excess of $12 \mathrm{lb} / 1000 \mathrm{ft}^{2}$ per year) to achieve maximum size, biomass, SPAD, or tissue TKN content. Similarly, Shurberg et al. (2012) reported that annual $\mathrm{N}$ applications in excess of $12 \mathrm{lb} / 1000 \mathrm{ft}^{2}$ were required for several landscape-grown cool- and warm-season annuals to reach maximum size, SPAD, biomass or tissue TKN. In a similar study, Chen et al. (2011) reported positive linear relationships between $\mathrm{N}$ rates $(0,1,2$, and $4 \mathrm{lb} / 1000 \mathrm{ft}^{2}$ ) and SI for cigar plant, 'Siskiyou Pink' gaura (Gaura lindheimeri), lantana, mexican heather (Cuphea hyssopifolia), purple coneflower (Echinacea purpurea), and rudbeckia. However, the authors found no significant differences in SI of gaura, mexican heather, or purple coneflower when supplied with 2 or $4 \mathrm{lb} / 1000$ $\mathrm{ft}^{2} \mathrm{~N}$ (Chen et al., 2011). Recommendations for $\mathrm{N}$ fertilizer designed to maximize plant growth characteristics would far exceed the current UF-IFAS Florida Friendly Landscaping ${ }^{\mathrm{TM}}$ program recommendations for ornamental plants grown in the landscape (Florida Department of Environmental Protection, 2010).

In contrast, the $\mathrm{N}$ rates required to achieve healthy, acceptable quality perennial plants fell within the UFIFAS Florida Friendly Landscaping ${ }^{\mathrm{TM}}$ program fertilizer recommendations for most of the perennial species we evaluated. Acceptable quality caladium and liriope were produced by applying as little as 0 to $2 \mathrm{lb} / 1000 \mathrm{ft}^{2}$ $\mathrm{N}$ annually, while growth did not peak for caladium or liriope receiving $\mathrm{N}$ at the $12 \mathrm{lb} / 1000 \mathrm{ft}^{2}$ annual rate. Other researchers have found similar growth responses for landscape-grown caladium planted in a sandy field soil in Florida. For example, Harbaugh and Overman (1984) reported an increase in tuber weight when caladium received fertilizer at $\mathrm{N}$ rates from 100 to $300 \mathrm{lb} /$ acre in field plots; however, the authors reported no increase in number of leaves (an indicator of plant quality) as fertilizer rate increased. As reported for caladium, $\mathrm{N}$ rates required to produce acceptable quality of the other evaluated perennial plants were much lower than needed to attain maximum growth. The results of our study suggest that high annual rates of $\mathrm{N}$ fertilizer $\left(>8 \mathrm{lb} / 1000 \mathrm{ft}^{2}\right)$ during the establishment phase (year one) may produce higher quality lantana and salvia; however, the $\mathrm{N}$ rate can be reduced considerably during the second year and still provide sufficient $\mathrm{N}$ to maintain the same level of quality for these species (Table 4). We suggest that lower $\mathrm{N}$ needs of established plants (year two) are likely due to the expanded root growth supplying greater $\mathrm{N}$ to the plant at this point. Previous research suggests that roots of container-grown ornamental shrubs are restricted to the planting hole for up to a year before root growth expands to the canopy dripline (Moore et al., 2009; Shober et al., 2009b; Wiese et al., 2009). Root growth of perennial landscape plants likely follows a similar pattern. Our study results support maintenance recommendations for lantana reported by Russ (2004), who suggested that lantana required very little fertilizer to maintain adequate health and quality after establishment. Russ (2004) noted that overfertilization may actually reduce lantana flowering and increase disease susceptibility, thereby reducing overall plant quality. Our findings supported this as lantana at 48,60 , and 66 WAP had reduced flower cover when supplied with fertilizer at the 12 $\mathrm{lb} / 1000 \mathrm{ft}^{2}$ annual $\mathrm{N}$ rate when compared with $\mathrm{N}$ applied at the other rates. Chen et al. (2011) also reported that fertilization of lantana in the first growing season at a rate of $2 \mathrm{lb} /$ $1000 \mathrm{ft}^{2} \mathrm{~N}$ produced higher quality plants than applying no fertilizer, but that little to no fertilizer was required in the second growing season to produce maximum growth and quality. Recent research conducted on a few perennial species in the landscape agrees with our findings that while size may increase for some species at higher fertilization rates, increasing the fertilizer rate did not result in increased plant quality (Chen et al., 2011). Chen et al. (2011) reported an increase in SI for some perennial species (cigar plant, rudbeckia, lantana) during the first growing season when $\mathrm{N}$ fertilizer was applied at higher $\mathrm{N}$ rates $\left(4 \mathrm{lb} / 1000 \mathrm{ft}^{2} \mathrm{~N}\right.$ compared with 0,1 , or $2 \mathrm{lb} / 1000$ $\mathrm{ft}^{2} \mathrm{~N}$ ), but found no corresponding increases in quality. Additionally, the authors found that there were few differences in SI at the higher rate by the second growing season (Chen et al., 2011). Although there is little research on fertilization needs of perennials in the landscape, our results support the maintenance recommendations of Park-Brown (2011) and 
Chen et al. (2011), who suggested that many herbaceous perennials will need very little fertilizer once they are established.

Based on results of our study, we suggest that low to moderate levels of $\mathrm{N}$ fertilization $\left(2\right.$ to $4 \mathrm{lb} / 1000 \mathrm{ft}^{2} \mathrm{~N}$ per year) will provide sufficient $\mathrm{N}$ to produce quality herbaceous landscape-grown perennials for the landscape. We suggest that basing fertilizer rates on $\mathrm{N}$ rates needed to achieve quality plants rather than maximum growth will provide sufficient $\mathrm{N}$ inputs for establishing and maintaining attractive herbaceous perennials in the landscape, while minimizing excess fertilizer available for leaching. Park-Brown (2011) similarly suggested that appearance (quality) can be a guide to the fertilizer needs of herbaceous perennials in the landscape in addition to growth rate. Likewise, Scoggins (2005) evaluated growth of 10 herbaceous perennial species in the greenhouse under different fertilizer rates $(50,150,250$, or $350 \mathrm{mg} \cdot \mathrm{L}^{-1}$ ) and found that while higher rates of fertilizer did increase growth of some species, acceptable levels of quality could generally be achieved at the lower fertilizer rates. Chen et al. (2011) also reported that fertilization at an annual $\mathrm{N}$ rate of 4 $\mathrm{lb} / 1000 \mathrm{ft}^{2} \mathrm{~N}$ increased the growth of landscape-grown cigar plant, lantana, and rudbeckia in the first growing season, but fertilization of these species at an annual $\mathrm{N}$ rate of $\mathrm{l} \mathrm{lb} /$ $1000 \mathrm{ft}^{2} \mathrm{~N}$ was sufficient to produce plants of "good" to "excellent" quality in year two.

This research was part of a larger study designed to validate and broaden $\mathrm{N}$ recommendations for Florida landscape plants. We acknowledge that additional factors such as soil fertility and type of mulch used in the landscape should be taken into account when making decisions about fertilization of landscape-grown perennials. Soil fertility can vary considerably. Additionally, conflicting results on $\mathrm{N}$ contributions of mulch to landscape planting beds suggest that mulch can immobilize a portion of available soil $\mathrm{N}$ (Cogger et al., 2008), or in some cases have no effect on plant foliar $\mathrm{N}$ (Cregg and Schutzki, 2009), depending on the type of mulch and plant species in question. We believe that fertilizer rate trials similar to our study are important because of the lack of a reliable $\mathrm{N}$ soil test.

\section{Literature cited}

Chen, Y., R.P. Bracy, A.D. Owings, and J.P. Quebedeaux. 2011. Controlledrelease fertilizer type and rate affect landscape establishment of seven herbaceous perennials. HortTechnology 21:336342.

Cogger, C., R. Hummel, J. Hart, and A. Bary. 2008. Soil and redosier dogwood response to incorporated and surface-applied compost. HortScience 43:2143-2150.

Cregg, B.M. and R. Schutzki. 2009. Weed control and organic mulches affect physiology and growth of landscape shrubs. HortScience 44:1419-1424.

Dubois, J.-J.B., S.L. Warren, and F.A. Blazich. 2000. Nitrogen nutrition of containerized Anemone $\times$ bybrida. J. Environ. Hort. 18:145-148.

Fisher, P.R., R.M. Wik, B.R. Smith, C.C. Pasian, M. Kmetz-González, and W.R. Argo. 2003. Correcting iron deficiency in calibrachoa grown in a container medium at high $\mathrm{pH}$. HortTechnology 13: 308-313.

Florida Department of Environmental Protection. 2010. Florida friendly best management practices for protection of water resources by the green industries. 11 Nov. 2011. <http://fyn.ifas.ufl.edu/pdf/ GIBMP_Manual_WEB_2_17_11.pdf $>$.

Harbaugh, B.K. and A.J. Overman. 1984. Evaluation of fertilizer types and rates on Caladium $\times$ hortulanum Birdsey 'Candidum' tuber production in muck and sandy soil management systems. Proc. Florida State Hort. Soc. 96:250-254.

Hipp, B.W., B.J. Simpson, and P.S. Graff. 1988. Influence of nitrogen and phosphorus on growth and tissue $\mathrm{N}$ and $\mathrm{P}$ concentration in Salvia greggii. J. Environ. Hort. 6:59-61.

Kidder, G., E.A. Hanlon, T.H. Yeager, and G.L. Miller. 2009. IFAS standardized fertilization recommendations for environmental horticulture crops. Univ. Florida, Inst. Food Agr. Sci. SL 141.

Line, D.E., N.M. White, D.L. Osmond, G.D. Jennings, and C.B. Mojonnier. 2002. Pollutant export from various land uses in the upper Neuse River Basin. Water Environ. Res. 74:100-108.

Macz, O., E.T. Paparozzi, and W.W. Stroup. 2001. Effect of nitrogen and sulfur applications on pot chrysanthemum production and postharvest performance. I. Leaf nitrogen and sulfur concentrations. J. Plant Nutr. 24:111-129.

Moore, K.A., A.L. Shober, E.F. Gilman, C. Wiese, S.M. Scheiber, M. Paz, and M. Brennan. 2009. Posttransplant growth of container-grown wild coffee, copperleaf, and orange jasmine is affected by irrigation frequency. HortTechnology 19:786791.

Mulvaney, R.L. 1996. Nitrogen-Inorganic forms, p. 1123-1184. In: D.L. Sparks, A.L. Page, P.A. Helmke, R.H. Loeppert, P.N. Soultanpour, M.A. Tabatabai, C.T. Johnston, and M.E. Sumner (eds.). Methods of soil analysis, Part 3: Chemical methods. Soil Sci. Soc. Amer., Madison, WI.

Mylavarapu, R.S. 2009. UF/IFAS Extension soil testing laboratory (ESTL) analytical procedures and training manual. Univ. Florida Inst. Food Agr. Sci. Circ. 1248 .

Nau, J. 1996. Ball perennial manual: Propagation and prodcution. Ball Publishing, Batavia, IL.

Park-Brown, S. 2011. Gardening with perennials in Florida. Univ. Florida, Inst. Food Agr. Sci. ENH 68.

Rose, M.A. 1999. Nutrient use patterns in woody perennials: Implications for increasing fertilizer efficiency in field-grown and landscape ornamentals. HortTechnology 9:613-617.

Russ, K. 2004. Lantana. Clemson Univ. HGIC 1177.

Sartain, J.B., L.T. Trenholm, E.F. Gilman, T.A. Obreza, and G. Toor. 2009. Frequently asked questions about landscape fertilization for Florida-friendly landscaping ordinances. Univ. Florida, Inst. Food Agr. Sci. ENH 1115.

Scoggins, H.L. 2005. Determination of optimum fertilizer concentration and corresponding substrate electrical conductivity for ten taxa of herbaceous perennials. HortScience 40:1504-1506.

Shober, A.L., S. Davis, M.D. Dukes, G.C. Denny, S.P. Brown, and S. Vyapari. 2009a. Performance of Florida landscape plants when irrigated by ET-based controllers and time-based methods. J. Environ. Hort. 27:251-256.

Shober, A.L., K.A. Moore, C. Wiese, S.M. Scheiber, E.F. Gilman, M. Paz, and M. Brennan. 2009b. Posttransplant irrigation frequency affects growth of container-grown sweet viburnum in three hardiness zones. HortScience 44:16831687.

Shurberg, G., A.L. Shober, C. Wiese, G. Denny, G.W. Knox, K.A. Moore, and M.C. Giurcanu. 2012. Response of landscapegrown warm- and cool-season annuals to nitrogen fertilization at five rates. HortTechnology 22:368-375.

University of Florida. 2010. Florida automated weather network, report generator. 
21 Oct. $2010 .<$ http://fawn.ifas.ufl.edu/ data/reports/>.

U.S. Department of Agriculture. 2004. Official soil series descriptions. 11 Nov. 2011. <http://soils.usda.gov/technical/ classification/osd/index.html>.

U.S. Environmental Protection Agency. 1993a. Method 353.2. Determination of nitrate-nitrite nitrogen by automated colorimetry, Environ. Monitoring Systems Lab., Office Res. Dev., U.S. Environ. Protection Agency, Cincinnati, $\mathrm{OH}$.
U.S. Environmental Protection Agency. 1993b. Method 350.1. Determination of ammonia nitrogen by semi-automated colorimetry, EPA-600/4-79-020, Environ. Monitoring Systems Lab., Office Res. Dev., U.S. Environ. Protection Agency, Cincinnati, $\mathrm{OH}$.

U.S. Environmental Protection Agency. 1993c. Method 351.2. Determination of total Kjeldahl nitrogen by semi-automated colorimetry, Environ. Monitoring Systems Lab., Office Res. Dev., U.S. Environ. Protection Agency, Cincinnati, $\mathrm{OH}$.
Wiese, C.L., A.L. Shober, E.F. Gilman, M. Paz, K.A. Moore, S.M. Scheiber, M.M. Brennan, and S. Vyapari. 2009. Effects of irrigation frequency during establishment on growth of Ilex cornuta 'Burfordii Nana' and Pittosporum tobira 'Variegata'. HortScience 44:14381443 .

Wright, R.D., B.E. Jackson, M.C. Barnes, and J.F. Browder. 2009. The landscape performance of annual bedding plants grown in pine tree substrate. HortTechnology 19:78-82. 